\title{
Effect of Computer Based Learning Regarding Airway Suctioning On knowledge and Skill Retention of Pediatric Nursing Students.
}

\author{
Nahla Abd Elnaby Elsayed: Assistant Lecturer of Pediatric Nursing, \\ Faculty of nursing, Tanta University \\ Prof. Dr. Rahma Soliman Bahgat: Professor of Pediatric Nursing, \\ Faculty of Nursing, Tanta University
}

Prof. Dr. Ahmed Mohammed Abd Erazek: Professor of Pediatric Medicine, Faculty of Medicine, Tanta University,

Prof. Dr. Mohammed Mohammed Ezat: Assistant Professor ofstatistic science, Faculty of Science, Tanta University,

Background: Computer-Based Learning (CBL) is an educational method that has been formed by combining computer technology and learning principles by oneself. The aim of this study was to design, implement computer based learning regarding airway suction and evaluate its effect on knowledge and skill retention of pediatric nursing students. A quasi experimental research design was used. The subjects: 150 pediatric nursing students in the third year, Faculty of Nursing, Tanta University. Materials and Method: Two tools were used to collect data: students' knowledge regarding airway suctioning and airway suctioning observational checklist. The Results revealed that the total scores of students' knowledge and practice for majority of study and control groups were unsatisfactory before teaching interventions and improved for both groups immediately, 2weeks, and 8 weeks with higher scores for study than control group. Conclusion: it can be concluded that there was a significant improvement in knowledge and skill retention of students studied with computer based learning method in relation to airway suctioning than students studied with traditional learning method. Recommendations: Medical and nursing education programs should adopt computer based learning in undergraduate education, and should support the introduction of computer based learning as an important step in curriculum development.

Key words: Computer-Based Learning, airway suction, knowledge and skill retention 


\section{Introduction:}

Most nursing education relies on two main modes of instruction: The traditional classroom instruction and the laboratory session; in each one, the teacher can do a number of things through continually observing students for check out their understanding. On the other hand, traditional classroom instruction is usually delivered by instructors through different types of learning, such as, lectures, discussions and demonstration. It requires a number of students to be active listeners; the role of the teacher is to educate the students on various subjects and life skills $^{(1)}$.

The learning technology is defined as the application of technology for the enhancement of teaching, learning and assessment. Learning technology includes computer based learning and multimedia materials and the use of networks and communication systems to support learning. Learning technology must become an integral part of the general education curriculum, where students' requirements and fundamental literacy expectations are quickly changing. So, education must change to meet future technology challenges ${ }^{(2)}$.

Computer based learning is an educational method which uses computers as an environment in which learning occurs, which enhances the learning period and students' motivation, and can be useful for students because of their different learning speeds. This educational method has been formed by combining computer technology and learning principles by oneself ${ }^{(3)}$.

Computer based learning is visually attractive, since it presents concepts using demonstrations that are made attractive by animation, color and sound. In addition, CBL captures and holds students' attention by providing opportunities for competition, with the students' previous performance as the opponent. ${ }^{(4)}$ Computer based learning also eliminates misconceptions by providing immediate feedback, since immediate feedback prevents incorrect learning concepts. In Computer-Assisted Learning $(\mathrm{CAL})$ rote learning is minimized and meaningful learning can occur. ${ }^{(5)}$

Computer assisted instruction software encompasses a variety of approaches, such as drill and practice, tutorial, simulation, and basic problem solving. The most valuable aspect of CAI is that is actively involves the learner in the learning process and instruction is individualized to meet learner needs. The student can set the pace, spend as much time on a subject as needed for mastery, and do so in a private, nonjudgmental environment. Computer programs have enormous possibilities for teaching fundamental as well as advanced 
skills. The computer is a reliable, attentive, and tolerant drill and practice partner. Computer assisted instructions offer consistent presentation of material and round- the clock accessibility. They are a time efficient and effective instructional method that reduces student- teacher ratios ${ }^{(6,7)}$.

Other advantages of computer instruction include interactivity, increased student motivation, increased access to information, instructional consistency, reduction of teacher's repetitive tasks, individualized instruction, time efficiency, and cost effectiveness. With computer use, educators can be freed from repetitive tasks that become burdensome and boring over time ${ }^{(8)}$.

Education in health care's today both patient education and nursing staff/student education is a topic of greatest interest to nurses in every setting in which they practice. Teaching is the major aspect of the nurse's professional role ${ }^{(9)}$. Findings indicate that nursing students had positive perception of the impact of using information technology on teaching and learning critical care nursing in Egypt ${ }^{(10)}$. Critical care nursing needs special skills and techniques for working with these patients, for who care can make a huge difference, often between life and death.
${ }^{(11)}$ As well, it needs critical thinking and problem solving skills ${ }^{(12)}$.

Airway suctioning is commonly employed in respiratory care to promote optimal airway patency in critically ill patient. ${ }^{(13)}$ Airway suctioning can prevent damage the cilia and interfere with mucus production leading to atelectasis, decreased oxygen saturation leading to hypoxemia, raised Intra Cranial Pressure(ICP), cardiac arrhythmias, respiratory arrest, and infection. ${ }^{(14)}$ Also airway suctioning is needed to maintain the patency and integrity of the artificial airways, decreased Peak Inspiratory Pressure (PIP), increased Tidal Volume (TV), and to obtain sputum specimen to rule out or identify pneumonia, other pulmonary infection or for sputum cytology. ${ }^{(15,16)}$

Nurses plays an crucial role in performing airway suctioning include making appropriate assessment of the child before suction such as heart rate and rhythm, respiratory rate, breath sounds, PIP in mechanically ventilated patient, and capillary oxygen saturation(SPO2). Preoxygenation of children immediately prior to suction procedure and maintenance of asepsis through hand hygiene, wearing gloves and protective clothing are essential nursing considerations. ${ }^{(17,18,19)}$ The nurse should select the appropriate suction 
catheter based on child age and endotracheal tube if present and she should determine level of suction pressure used according child age ${ }^{(20,21)}$.

During suctioning the nurse should observe cardiopulmonary parameters .After suctioning the nurse should assess heart rate and rhythm, respiratory rate and oxygenation. Chest auscultation should also be performed. Sputum should be observed for color, amount and consistency and child reaction ${ }^{(22,23)}$. The nurse should document the specific suction procedure used as well as the effects or outcomes and side effects ${ }^{(24,25)}$

The aim of the study was to design, implement computer based learning regarding airway suction and evaluate its effect on knowledge and skill retention of pediatric nursing students

\section{Research Hypothesis}

Is computer based learning more effective than traditional training of airway suctioning regarding knowledge and skill retention on short and medium term follow up.

\section{Materials and Method}

\section{Materials}

\section{Research design}

A quasi- experimental research design was used in this study.

Setting: The study was conducted at:

1- The clinical laboratory skills for third year pediatric nursing students contain pediatric simulators, equipment and supplies.

2- The computer laboratory where 50 personal computers are available at Faculty of Nursing, Tanta University.

Subjects: A total sample of 150 pediatric nursing students in the third year, Faculty of Nursing, Tanta University. Study subjects were recruited from total population of female and male gender $(\mathrm{N}=275)$ who were studying pediatric nursing in the second semester during the academic year (2015- 2016).The sample was selected randomly.

Group 1: Control group included 75 students studying with traditional training as lecture and demonstration methods.

Group 2: Study group included 75 students studying with computer based training module.

\section{Tools of data collection:}

Two tools were used to collect data. These tools included the following.

Tool 1: Students' knowledge regarding airway suctioning.

\section{A structured questionnaire sheet:}

It was developed by the researcher after reviewing the related literatures to assess the students' knowledge regarding airway suctioning it compromised two main parts:

First part: It covered biosocial characteristic of the studied students which 
include: Age, sex and attendance of related clinical training.

Second part: It covered the students' knowledge regarding airway suctioning. It was designed in multiple choice questions from (MCQ) and was revised by pediatric nursing experts. The test was composed of 28 multiple choice questions that covered all knowledgeable items of airway suctioning. This tool was used at 4 points of time. Fist time prior to teaching intervention (pretest) then repeat it immediately following sessions (immediate, follow up), 2weeks later (short term follow up) and a further 8 weeks later (medium term follow up).

Knowledge items covered in this tool were definition of airway suction, purposes of airway suction, assessment need for airway suction, preparation of airway suction, implementation of the procedure, post care, complications, contraindications, and documentation. The possible total score for the factual knowledge ranged from (0) to (28), one point (1) for each correct answer and the incorrect answer scored (0).

The total score of the students' knowledge equal $100 \%$ and accordingly the student's answers was classified as follows:

- Satisfactory knowledge (60\% or more)

- Unsatisfactory knowledge (less than 60\%)
Tool II: airway suctioning observational checklist:

An airway suctioning observational checklist developed by the researcher to assess the students' performance of natural and artificial airway suctioning that is already included in pediatric nursing clinical book developed by pediatric nursing staff which updated every year after reviewing related literature.

This tool was used at 3 points of time, first time immediately following sessions then 2 weeks later (short term follow up) and a further 8 weeks later (medium term follow up).

It consisted of 5 performance categories assessment, preparation of equipment and patient, implementation, post care and documentation that made together steps for each one of the procedures.

Each item of practice was evaluated as follows:

- Correct done was scored (1)

- Not done or incorrect done was scored (0)

The observational checklist was consisted of (40) items and the total score for all items in observational checklist was (40). It was filled out by the researcher.

The total score of the students' practice equal $100 \%$ and accordingly the student's answers was classified as follows: 
- Satisfactory practice (60\% or more)

- Unsatisfactory practice (less than 60\%)

\section{Method:}

1- An official permission was obtained from the dean of Faculty of Nursing, Tanta University after clarifying the purpose of the study, setting the time for beginning the study.

2- Students consent to participate in this study were obtained after explaining of the aim of the study.

3- Ethical consideration: Ethical approval was obtained from the research ethics committee of faculty of nursing, Tanta University. The students were reassured that the obtained information was confidential and used only for purpose of the study and that results would not contribute to their grades or affect their academic progress. The content of the CBL module was given to control group after evaluation of both groups.

4- Content validity: The Tools of the study were tested for content validity by the supervisors of this thesis and the experts in the field of pediatrics nursing. Modifications were carried out accordingly.

5- Pilot study: Study was conducted on $10 \%$ of students (25students) were selected randomly (who studying pediatric nursing in the first semester
2015-2016) from the same setting and were excluded from the study sample to evaluate the clarity and applicability of the computer module and research tools, estimate approximate time required for data collection, identify problems may hinder data collection and measures to overcome them. Necessary modifications after pilot study were done. Some questions were added and others were omitted.

6- Tools development: Two tools were used in this study.

7- Phases of the study: The study was conducted on three phases:

\section{1-Assessment Phase:}

It was carried out by the researcher for all study subjects to collect baseline data of this study and to assess students' knowledge about airway suction (Tool I). 2-Implementation Phase was included the following steps:

\section{Setting objective.}

-The content in knowledge section consisted of definition, purpose, indication, contraindication, complication and principles of airway suction. The principle section includes information about assessment need, preparation, implementation, post care and documentation for airway suction.

-Performance section consisted of natural and artificial airway suctioning 
procedures which classified into assessment, preparation, implementation, post care and documentation.

Preparation of the content which covered the reason behind the application of the sessions. The computer module was developed by the assistance of a technologist using a combination of tutorials (text only), interactive multimedia, high quality photographs were also included to stimulate interest. The theoretical content was identical of to that of the traditional teaching sessions. The airway suctioning demonstration videos were embedded within the module and could be viewed by participant as required.

- This computer module was composed: The content in knowledge section definition, purpose, indication, contraindication, complication and principles of airway suction. The principle section includes information about assessment need, preparation, implementation, post care and documentation for airway suction. Procedures for different types of airway suctioning that explained all the steps of the practice with each. This part was presented by using flash program that was containing text, pictures, and videos.

- Performance section consisted of oral, nasal, endotracheal and tracheostomy airway suctioning procedures which classified into assessment, preparation, implementation, post care and documentation. When playing the procedure movie, the student found flexible moving between the different videos (oral, nasal, endotracheal and tracheostomy airway suctioning procedures) by affixed play bar that enabled moving play, previous or next buttons.

- The test yourself-section was including 15 multiple choice questions about airway suction which was interactive part. The computer spoke the written statement of each question, and then the student had to choose the right answer. After finishing the answers and submitting them, the computer had to tell him his score with a comment of either praising or supporting him in addition to offering a review for the questions.

Frist, information about the study was provided which included an explanation of the purpose and design of the study.

Pretest of the knowledge part of airway suctioning was distributed on the whole of the students at the beginning of the second semester to the study subject sample and at the same time, it had been collected by the researcher. 


\section{Control group:}

- The students in the control group were studying using traditional methods of teaching, face to face lecture for knowledge section and demonstration and remonstration for performance section in pediatric nursing laboratory. The students in control group was divided into two groups in two pediatric laboratory skill labs and received the content of airway suction by two pediatric staff at the same time, one of them was the researcher.

- The students in control group already had the clinical book which contain all pediatric nursing procedures including airway suctioning procedures

- Prior to immediate knowledge test the researcher explained the test instructions that included the following: Each item had only one correct answer to be chosen and no further comments were offered.

- Immediate knowledge test and immediate performance checklist were completed at the end of the teaching session. The researcher told the student the date and the time they had to attend for 2 weeks follow up.

- 2weeks follow up knowledge test and performance check list were completed in the same way and the researcher told the student the date and the time they had to attend for 8 weeks follow up.
- 8weeks follow up knowledge test and performance checklist was completed in the same way.

\section{Study group:}

- The students in study group worked independently using computer based learning module via an individual computer at the faculty computer laboratory. The students of the study group were divided into two groups as the computer lab only consists of 50 computers. The theoretical content was identical to that of the traditional teaching. The oral, nasal, endotracheal and tracheostomy airway suctioning demonstration videos were embedded within the module and could be viewed by participants.

- A brief explanation to the linked features using computer based learning module was done to participants in the study group. Participants in study group were instructed to work through the module independently for the duration of the session.

- Teaching sessions for study group were 4 sessions and these sessions were repeated 4 times prior to each period of data collection.

- First session: consisted of computer module and students were allowed to study the oropharyngeal suctioning video. 
- Second sessions: consisted of computer module and students were allowed to study the nasopharyngeal suctioning video.

- Third session: consisted of computer module and students were allowed to study the endotracheal suctioning video.

- Fourth session: consisted of computer module and students were allowed to study the tracheostomy suctioning video

- Prior to immediate knowledge test the researcher explained the test instructions that included the following: Each item had only one correct answer to be chosen and no further comments were offered.

- Immediate knowledge test and immediate performance checklist were completed at pediatric lab at the end of the teaching session. The researcher told the student the date and the time they had to attend for 2 weeks follow up.

- 2weeks follow up knowledge test and performance check list were completed in the same way and the researcher told the student the date and the time they had to attend for 8 weeks follow up.

- 8weeks follow up knowledge test and performance checklist was completed in the same way.

\section{3-Evaluation Phase:}

- The evaluation had been done before, immediately, 2 weeks follow up and 8 weeks follow up for the knowledge items for study and control groups.

- The evaluation was done immediately, 2 weeks and 8 weeks after teaching interventions for performance section for both groups.

\section{Statistical Analysis:}

The collected data was organized, tabulated, and statistically analyzed using SPSS software statistical computer package version 20. For quantitative variables, mean and standard deviations were calculated. For qualitative variables, the number and percentage distribution were calculated. Chi-square test was used to examine the relation between qualitative variables. Fisher exact test (p) was used to compare observations before, immediately and 2 weeks and 8 weeks following teaching interventions. Significance was adopted at $p<0.05$ for interpretation of results of tests of significance.

\section{Results:}

Table (1) represents Percentage distribution of knowledge about airway suction for study and control groups before teaching intervention. This table shows that there were no statistically significant differences between the study and control 
groups before teaching interventions regarding definition, purpose, assessment need, preparation, implementation, post care, complication, contraindication and documentation of airway suction in the students sheet $(p=0.0109, p=0.236, p=136$, $\mathrm{p}=0.941, \quad \mathrm{p}=0,101, \quad \mathrm{p}=0.139, \quad \mathrm{p}=0.513$, $\mathrm{p}=0.611$, and $\mathrm{p}=0.513$ ) respectively. Regarding the relation between study and control group immediately after teaching intervention, it was observed that there were no statistically significant differences between the study and control groups regarding definition, purpose, assessment need, preparation, implementation, post care, complication, contraindication and documentation of airway suction in the students' sheet $\quad(p=0.281, \quad p=1.000$, $\mathrm{p}=1.000, \quad \mathrm{p}=0.689, \quad \mathrm{p}=0.151$, $\mathrm{p}=0.554, \mathrm{p}=0.844, \mathrm{p}=0.739$ and $\mathrm{p}=1.000$ ) respectively

On the other hand there were statistically significant difference in the study group knowledge regarding definition, purpose, assessment need, preparation, implementation, post care, complication, contraindication and documentation of airway suction in the students sheet $(p=0.000)$ before and immediately after teaching intervention. Also there were statistically significant difference in the control group knowledge regarding definition, purpose, assessment need, preparation, implementation, post care, complication, contraindication and documentation of airway suction in the students sheet $(p=0.001, p=0.001, p=0.005$, $\mathrm{p}=0.000, \quad \mathrm{p}=0.000, \mathrm{p}=0.001, \quad \mathrm{p}=0.000$, $\mathrm{p}=0.006$ and $\mathrm{p}=0.001$ ) respectively before and immediately after teaching interventions.

Table (2) illustrates Percentage distribution of knowledge about airway suction for study and control groups 2 weeks and 8weeks following teaching intervention. This table shows that there were statistically significant differences between the study and control groups regarding definition, purpose, assessment need, preparation, implementation, post care, complication, contraindication and documentation of airway suction in the students' $\operatorname{sheet}(\mathrm{p}=0.000, \mathrm{p}=0.012, \mathrm{p}=0.027$, $\mathrm{p}=0.001, \mathrm{p}=0.003, \mathrm{p}=0.014, \mathrm{p}=0.008$, $\mathrm{p}=0.004$ and $\mathrm{p}=0.004)$ respectively before teaching intervention. Regarding the relation between study and control group 8 weeks follow up after teaching intervention, it was observed that there were statistically significant differences between the study and control groups regarding definition, purpose, assessment need, preparation, implementation, post care, complication, contraindication and documentation of airway suction in the students' sheet $(\mathrm{p}=0.000, \quad \mathrm{p}=0.001$, 
$\mathrm{p}=0.002, \quad \mathrm{p}=0.009, \quad \mathrm{p}=0.002, \quad \mathrm{p}=0.001$, $\mathrm{p}=0.047, \quad \mathrm{p}=0.034$ and $\mathrm{p}=0.006$ ) respectively.

On the other hand There were no statistically significant difference in the study group knowledge regarding definition, purpose, assessment need, implementation, post care, complication, contraindication and documentation of airway suction in the students' sheet $(\mathrm{p}=$ 0.774, $\mathrm{p}=0.166, \quad \mathrm{p}=0.273, \quad \mathrm{p}=0.132$, $\mathrm{p}=0.111, \quad \mathrm{p}=0.099, \quad \mathrm{p}=0.644 \quad$ and $\mathrm{p}=0.545$ )respectively before and immediately after teaching intervention.There were statistically significant difference in the control group knowledge regarding purpose, preparation, and post care of airway suction in the students' sheet $(p=0.026$, $\mathrm{p}=0.040$ and $\mathrm{p}=0.013$ ) respectively before and immediately after teaching intervention.

Table (3) shows percentage distribution of the study and control groups practice regarding assessment signs and symptoms indicating upper airway secretion during oropharyngeal and nasopharyngeal suction immediately and 2 weeks following teaching intervention. It was observed that the majority of the study group $(81.1 \%)$ give correct answer about assessing signs and symptoms indicating upper airway secretion immediately after teaching intervention and (79.3\%) for the control group with no statistically significant difference between two groups $(\mathrm{p}=0.503)$ after teaching interventions.

As regard the study group students practice 2 weeks after the teaching intervention it was found that the majority of them(78.2\%) give correct answer about assessing signs and symptoms indicating upper airway secretion during oropharyngeal and nasopharyngeal suction compared to more than half of the control group $(54.4 \%)$ with statistically significant difference between two groups $(\mathrm{p}=0.000)$ at 2 weeks following teaching interventions.

This table shows that there were no statistically significant difference in the study group practice regarding assessing signs and symptoms indicating upper airway secretion during oropharyngeal and nasopharyngeal suction in the students' sheet $(\mathrm{p}=0.282)$ immediately after and 2 weeks following teaching interventions. While there were statistically significant difference in the control group practice regarding assessing signs and symptoms indicating upper airway secretion in the students' sheet $(\mathrm{p}=0.000)$ immediately after and 2 weeks following teaching intervention.

Table (4) shows percentage distribution of the study and control groups practice regarding intervention and implementation 
of airway suction during oropharyngeal and nasopharyngeal suction suction immediately and 2 weeks following teaching intervention. It was observed that the majority of the study group (79.5 $\%)$ did the steps correctly about intervention and implementation during oropharyngeal and nasopharyngeal suction immediately after teaching intervention and $(74.5 \%)$ for the control group with statistically significant difference between two $\operatorname{groups}(\mathrm{p}=0.003)$ immediately after teaching interventions .

It was observed that the majority of the study group (79.5\%)did the steps correctly about intervention and implementation during oropharyngeal and nasopharyngeal suction at 2 weeks follow up after teaching interventions compared to more than half of the control group (57\%) with statistically significant difference between two groups $(\mathrm{p}=0.000)$ at 2 weeks follow up after teaching interventions

It was observed that there were no statistically significant difference in the study group practice regarding intervention and implementation during oropharyngeal and nasopharyngeal suction in the students' sheet $(\mathrm{p}=1.000)$ immediately after and 2 weeks following teaching interventions. While there were statistically significant difference in the control group practice regarding intervention and implementation during oropharyngeal and nasopharyngeal suction in the students' sheet $(\mathrm{p}=0.000)$ immediately after and 2 weeks following teaching interventions.

Table (5)shows percentage distribution of the study and control groups practice regarding post care after airway suction during endotracheal and tracheostomy suction immediately after and 2 weeks following teaching interventions. It was observed that the majority of the study group $(85.9 \%)$ did the steps correctly about post care after airway suction during endotracheal and tracheostomy suction immediately after teaching intervention and $(74.7 \%)$ for the control group with statistically significant difference between two groups $(\mathrm{p}=0.000)$ immediately after teaching interventions.

It was observed that the majority of the study group (92.5\%)did the steps correctly about post care after airway suction during endotracheal and tracheostomy suction at 2 weeks follow up after teaching interventions compared to nearly two third of the control group (68\%) with statistically significant difference between two groups $(\mathrm{p}=0.000)$ at 2 weeks follow up after teaching interventions.

It was observed that there were no statistically significant difference in the study group practice regarding post care after airway suction during endotracheal 
and tracheostomy suction in the students' sheet $(\mathrm{p}=0.194)$ immediately after and 2 weeks following teaching interventions. Also there were no statistically significant difference in the control group practice regarding post care after airway suction during endotracheal and tracheostomy suction in the students' sheet $(p=0.264)$ immediately after and 2 weeks following teaching interventions.

Table(6) shows percentage distribution of the study and control groups practice regarding documentation after airway suction during endotracheal and tracheostomy suction immediately after and 2 weeks following teaching interventions. It was observed that the more than two third of the study group (77.5\%)did the steps correctly about documentation after airway suction during endotracheal and tracheostomy suction immediately after teaching intervention and more than two third of the control group $(68.7 \%)$ with statistically significant difference between two groups $(\mathrm{p}=0.001)$ immediately after teaching interventions.

It was observed that more than two third of the study group (73.7\%) did the steps correctly about documentation after airway suction during endotracheal and tracheostomy suction at 2 weeks follow up after teaching interventions compared to nearly two third of the control group (64
$\%$ ) with statistically significant difference between two groups $(\mathrm{p}=0.000)$ at 2 weeks follow up after teaching interventions.

It was observed that there were no statistically significant difference in the study group practice regarding documentation after airway suction during endotracheal and tracheostomy suction in the students' sheet $(\mathrm{p}=0.122)$ immediately after and 2 weeks following teaching interventions. While there were statistically significant difference in the control group practice regarding documentation after airway suction during endotracheal and tracheostomy suction in the students' sheet $(\mathrm{p}=0.000)$ immediately after and 2 weeks following teaching interventions.

Table (7) represents the total scores of the control and study group knowledge regarding airway suction before, immediately after, 2 weeks follow up, and 8 weeks follow up. It was observed that the total score for the majority of the study and control group $(94.7 \%$ and $86.7 \%)$ respectively were un satisfactory before the teaching interventions while the majority of the study and control group $(98.7 \%$ and $92 \%$ ) respectively were satisfactory immediatelyafter the teaching interventions.

In relation to the total score of the study and control group knowledge regarding airway suction at 2 weeks follow up. It was 
observed that the majority of the study group (98.7\%) while two third of the control group $(66.7 \%)$ were satisfactory. As regard the total score of the study and control group knowledge regarding airway suction at 8 weeks follow up, it was observed that the majority of the study group $(98.7 \%)$ while nearly two third of the control group(58.7)were satisfactory. Table (8) represents the total scores of the control and study group performance regarding airway suction before, immediately after, 2 weeks follow up, and 8 weeks follow up. It was observed that the total score for the majority of the study and control group $(93.3 \%$ and $80 \%)$ respectively were satisfactory immediately after the teaching interventions.

In relation to the total score of the study and control group knowledge regarding airway suction at 2 weeks follow up. It was observed that the majority of the study group $(90.7 \%)$ while one third of the control group (33.3\%) was satisfactory. As regard the total score of the study and control group knowledge regarding airway suction at 8 weeks follow up, it was observed that the majority of the study group $(89.3 \%)$ while nearly one third of the control group(22.7\%)were satisfactory 


\section{Tanta Scientific Nursing Journal}

Table (1) Percentage distribution of knowledge about airway suction for study and control groups before and immediately after teaching intervention.

\begin{tabular}{|c|c|c|c|c|c|c|c|c|c|c|c|c|c|c|c|c|c|c|c|c|}
\hline \multirow{4}{*}{ Students' knowledge } & \multicolumn{9}{|c|}{$\begin{array}{l}\text { Before } \\
\text { the teaching intervention }\end{array}$} & \multicolumn{9}{|c|}{$\begin{array}{l}\text { Immediately after } \\
\text { the teaching intervention }\end{array}$} & \multirow{4}{*}{$\begin{array}{c}\text { P1\&P2 } \\
\\
\begin{array}{c}\text { Study } \\
\text { group }\end{array} \\
\\
\begin{array}{c}\text { Chi } \\
\text { p-value }\end{array}\end{array}$} & \multirow{4}{*}{$\begin{array}{c}\text { P1\&P } \\
\\
\begin{array}{r}\text { Contro } \\
\text { group }\end{array} \\
\\
\begin{array}{c}\text { Chi } \\
\text { p-valu }\end{array}\end{array}$} \\
\hline & \multicolumn{4}{|c|}{$\underset{(n=75)}{\text { Study group }}$} & \multicolumn{4}{|c|}{$\begin{array}{c}\text { Control group } \\
(\mathrm{n}=75)\end{array}$} & \multirow{3}{*}{$\underset{\text { p-value }}{\text { Chi }}$} & \multicolumn{4}{|c|}{$\begin{array}{c}\text { Study group } \\
(\mathrm{n}=\mathbf{7 5})\end{array}$} & \multicolumn{4}{|c|}{$\begin{array}{c}\text { Control group } \\
(\mathrm{n}=75)\end{array}$} & \multirow{3}{*}{$\underset{\text { p-value }}{\text { Chi }}$} & & \\
\hline & \multicolumn{2}{|c|}{ Correct } & \multicolumn{2}{|c|}{ Incorrect } & \multicolumn{2}{|c|}{ Correct } & \multicolumn{2}{|c|}{ Incorrect } & & \multicolumn{2}{|c|}{ Correct } & \multicolumn{2}{|c|}{ Incorrect } & \multicolumn{2}{|c|}{ Correct } & \multicolumn{2}{|c|}{ Incorrect } & & & \\
\hline & No. & $\%$ & No & $\%$ & No. & $\%$ & No. & $\%$ & & No. & $\%$ & No. & $\%$ & No. & $\%$ & No. & $\%$ & & & \\
\hline $\begin{array}{l}\text { Definition of airway } \\
\text { suction }\end{array}$ & 33 & 44.4 & 42 & 55.6 & 39 & 52 & 36 & 48 & $\begin{array}{l}2.572 \\
0.109\end{array}$ & 68 & 91.1 & 7 & 8.89 & 66 & 88 & 9 & 12 & $\begin{array}{l}1.164 \\
0.281\end{array}$ & $\begin{array}{l}112.182 \\
0.000^{* * *}\end{array}$ & $\begin{array}{l}15.180 \\
0.001 *\end{array}$ \\
\hline $\begin{array}{l}\text { Purpose for airway } \\
\text { suction }\end{array}$ & 39 & 52 & 36 & 48 & 42 & 56 & 33 & 44 & $\begin{array}{l}0.242 \\
0.236\end{array}$ & 61 & 81.3 & 14 & 18.7 & 61 & 81.3 & 14 & 18.7 & $\begin{array}{l}0.001 \\
1.000\end{array}$ & $\begin{array}{l}43.042 \\
0.000^{* * *}\end{array}$ & $\begin{array}{l}11.186 \\
0.001 *\end{array}$ \\
\hline $\begin{array}{l}\text { Assessment need for } \\
\text { airway suction }\end{array}$ & 30 & 40 & 45 & 60 & 44 & 58.7 & 31 & 41.3 & $\begin{array}{l}2.218 \\
0.136\end{array}$ & 60 & 80 & 15 & 20 & 60 & 80 & 15 & 20 & $\begin{array}{l}0.001 \\
1.000\end{array}$ & $\begin{array}{r}25.000 \\
0.000 * *\end{array}$ & $\begin{array}{l}8.027 \\
0.005^{*}\end{array}$ \\
\hline $\begin{array}{l}\text { Preparation of airway } \\
\text { suction }\end{array}$ & 31 & 41.1 & 44 & 58.9 & 44 & 41.3 & 47 & 58.7 & $\begin{array}{l}0.006 \\
0.941\end{array}$ & 53 & 71.2 & 22 & 28.8 & 52 & 69.9 & 23 & 30.1 & $\begin{array}{l}0.160 \\
0.689\end{array}$ & $\begin{array}{c}69.142 \\
0.000^{* *}\end{array}$ & $\begin{array}{c}61.837 \\
0.000 * *\end{array}$ \\
\hline $\begin{array}{l}\text { Implementation of the } \\
\text { procedure }\end{array}$ & 28 & 37.33 & 62.67 & 57.8 & 31 & 41.1 & 44 & 58.9 & $\begin{array}{l}2.694 \\
0.101\end{array}$ & 63 & 84.1 & 12 & 15.9 & 61 & 81.56 & 14 & 18.4 & $\begin{array}{l}2.067 \\
0.151\end{array}$ & $\begin{array}{l}412.855 \\
0.000 * *\end{array}$ & $\begin{array}{c}310.82 \\
0.000\end{array}$ \\
\hline Post care & 29 & 38.7 & 46 & 61.3 & 38 & 50.7 & 37 & 49.3 & $\begin{array}{l}2.185 \\
0.139\end{array}$ & 60 & 80 & 15 & 20 & 57 & 76 & 18 & 24 & $\begin{array}{l}0.350 \\
0.554\end{array}$ & $\begin{array}{c}26.552 \\
0.000^{* * *}\end{array}$ & $\begin{array}{l}10.364 \\
0.001 *\end{array}$ \\
\hline Complication & 37 & 49.3 & 38 & 50.7 & 33 & 44 & 42 & 56 & $\begin{array}{l}0.429 \\
0.513\end{array}$ & 59 & 78.7 & 16 & 21.3 & 58 & 22.7 & 17 & 22.7 & $\begin{array}{l}0.039 \\
0.844\end{array}$ & $\begin{array}{c}14.005 \\
0.000^{* * *}\end{array}$ & $\begin{array}{l}17.461 \\
0.000 *:\end{array}$ \\
\hline Contraindication & 26 & 34.7 & 49 & 65.3 & 29 & 38.7 & 46 & 61.3 & $\begin{array}{l}0.258 \\
0.611 \\
\end{array}$ & 44 & 58.7 & 31 & 41.3 & 46 & 61.3 & 29 & 38.7 & $\begin{array}{l}0.111 \\
0.739 \\
\end{array}$ & $\begin{array}{c}8.679 \\
0.000^{* * *}\end{array}$ & $\begin{array}{l}7.707 \\
0.006 *\end{array}$ \\
\hline Documentation & 38 & 50.7 & 37 & 49.3 & 42 & 56 & 33 & 44 & $\begin{array}{l}0.429 \\
0.513\end{array}$ & 61 & 81.3 & 14 & 18.7 & 61 & 81.3 & 14 & 18.7 & $\begin{array}{l}0.001 \\
1.000\end{array}$ & $\begin{array}{l}15.716 \\
0.000^{* * *}\end{array}$ & $\begin{array}{l}11.186 \\
0.001 *\end{array}$ \\
\hline
\end{tabular}

*Significance at level $\mathrm{P}<0.05$ 
Table (2) Percentage distribution of knowledge about airway suction for study and control groups 2 weeks and 8weeks following teaching intervention

\begin{tabular}{|c|c|c|c|c|c|c|c|c|c|c|c|c|c|c|c|c|c|c|c|c|}
\hline \multirow{4}{*}{$\begin{array}{l}\text { Students' } \\
\text { knowledge }\end{array}$} & \multicolumn{9}{|c|}{$\begin{array}{l}2 \text { week after } \\
\text { the teaching intervention }\end{array}$} & \multicolumn{9}{|c|}{$\begin{array}{l}8 \text { week after } \\
\text { the teaching intervention }\end{array}$} & \multirow{4}{*}{$\begin{array}{c}\text { P3\&P4 } \\
\\
\text { Study } \\
\text { group } \\
\\
\begin{array}{c}\text { Chi } \\
\text { p-value }\end{array}\end{array}$} & \multirow{4}{*}{ 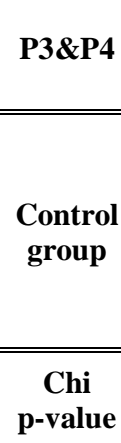 } \\
\hline & \multicolumn{4}{|c|}{$\begin{array}{l}\text { Study group } \\
\quad(\mathbf{n}=75)\end{array}$} & \multicolumn{4}{|c|}{$\begin{array}{c}\text { Control group } \\
(n=75)\end{array}$} & \multirow{3}{*}{$\begin{array}{c}\text { Chi } \\
\text { p-value }\end{array}$} & \multicolumn{4}{|c|}{$\begin{array}{l}\text { Study group } \\
\quad(\mathbf{n}=75)\end{array}$} & \multicolumn{4}{|c|}{$\begin{array}{l}\text { Control group } \\
\qquad(n=75)\end{array}$} & \multirow{3}{*}{$\begin{array}{c}\text { Chi } \\
\text { p-value }\end{array}$} & & \\
\hline & \multicolumn{2}{|c|}{ Correct } & \multicolumn{2}{|c|}{ Incorrect } & \multicolumn{2}{|c|}{ Correct } & \multicolumn{2}{|c|}{ Incorrect } & & \multicolumn{2}{|c|}{ Correct } & \multicolumn{2}{|c|}{ Incorrect } & \multicolumn{2}{|c|}{ Correct } & \multicolumn{2}{|c|}{ Incorrect } & & & \\
\hline & No. & $\%$ & No & $\%$ & No. & $\%$ & No. & $\%$ & & No. & $\%$ & No. & $\%$ & No. & $\%$ & No. & $\%$ & & & \\
\hline $\begin{array}{l}\text { Definition of } \\
\text { airway suction }\end{array}$ & 69 & 92.4 & 6 & 7.6 & 52 & 69.3 & 23 & 30.7 & $\begin{array}{c}12.354 \\
0.000 * *\end{array}$ & 68 & 91.1 & 7 & 8.89 & 50 & 66.7 & 25 & 33.3 & $\begin{array}{c}12.871 \\
0.000 * *\end{array}$ & $\begin{array}{l}0.084 \\
0.774\end{array}$ & $\begin{array}{l}0.123 \\
0.726\end{array}$ \\
\hline $\begin{array}{l}\text { Purpose for } \\
\text { airway suction }\end{array}$ & 67 & 89.3 & 8 & 10.7 & 55 & 73.3 & 20 & 26.7 & $\begin{array}{c}6.323 \\
0.012 *\end{array}$ & 61 & 81.3 & 14 & 18.7 & 42 & 56 & 33 & 44 & $\begin{array}{l}11.186 \\
0.001 *\end{array}$ & $\begin{array}{l}1.918 \\
0.166\end{array}$ & $\begin{array}{c}4.931 \\
0.026 *\end{array}$ \\
\hline $\begin{array}{l}\text { Assessment need } \\
\text { for airway } \\
\text { suction }\end{array}$ & 65 & 86.7 & 10 & 13.3 & 54 & 72 & 21 & 28 & $\begin{array}{l}4.920 \\
0.027 *\end{array}$ & 60 & 80 & 15 & 20 & 42 & 56 & 33 & 44 & $\begin{array}{l}9.926 \\
0.002 *\end{array}$ & $\begin{array}{l}1.200 \\
0.273\end{array}$ & $\begin{array}{l}1.601 \\
0.602\end{array}$ \\
\hline $\begin{array}{l}\text { Preparation of } \\
\text { airway suction }\end{array}$ & 70 & 93.3 & 5 & 6.7 & 55 & 73.3 & 20 & 26.7 & $\begin{array}{l}\text { 10.800 } \\
0.001 *\end{array}$ & 58 & 77.3 & 17 & 22.7 & 43 & 57.3 & 32 & 42.7 & $\begin{array}{c}6.820 \\
0.009 *\end{array}$ & $\begin{array}{l}7.670 \\
0.006 *\end{array}$ & $\begin{array}{l}4.239 \\
0.040 *\end{array}$ \\
\hline $\begin{array}{l}\text { Implementation } \\
\text { of the procedure }\end{array}$ & 69 & 92.2 & 6 & 7.78 & 55 & 73.3 & 20 & 26.7 & $\begin{array}{l}9.119 \\
0.003 * \\
\end{array}$ & 63 & 84 & 12 & 16 & 46 & 61.3 & 29 & 38.7 & $\begin{array}{l}9.700 \\
0.002 *\end{array}$ & $\begin{array}{l}2.273 \\
\mathbf{0 . 1 3 2} \\
\end{array}$ & $\begin{array}{l}\mathbf{2 . 4 5 5} \\
\mathbf{0 . 1 7 7} \\
\end{array}$ \\
\hline Post care & 63 & 84 & 12 & 16 & 50 & 66.7 & 25 & 33.3 & $\begin{array}{c}6.063 \\
0.014 * \\
\end{array}$ & 55 & 73.3 & 20 & 26.7 & 35 & 46.7 & 40 & 53.3 & $\begin{array}{l}11.111 \\
0.001 * \\
\end{array}$ & $\begin{array}{l}2.542 \\
0.111\end{array}$ & $\begin{array}{c}6.109 \\
0.013 * \\
\end{array}$ \\
\hline Complication & 59 & 78.7 & 16 & 21.3 & 44 & 58.7 & 31 & 41.3 & $\begin{array}{l}6.972 \\
0.008 *\end{array}$ & 50 & 66.7 & 25 & 33.3 & 38 & 50.7 & 37 & 49.3 & $\begin{array}{l}3.959 \\
0.047 *\end{array}$ & $\begin{array}{l}2.719 \\
0.099\end{array}$ & $\begin{array}{l}0.968 \\
0.325 \\
\end{array}$ \\
\hline Contraindication & 65 & 86.7 & 10 & 13.3 & 50 & 66.7 & 25 & 33.3 & $\begin{array}{c}8.385 \\
0.004 * \\
\end{array}$ & 63 & 84 & 12 & 16 & 52 & 69.3 & 23 & 30.7 & $\begin{array}{l}4.509 \\
0.034 * \\
\end{array}$ & $\begin{array}{l}0.213 \\
0.644 \\
\end{array}$ & $\begin{array}{l}\mathbf{0 . 1 2 3} \\
\mathbf{0 . 7 2 6} \\
\end{array}$ \\
\hline Documentation & 61 & 81.3 & 14 & 18.7 & 45 & 60 & 30 & 40 & $\begin{array}{c}8.233 \\
0.004 * \\
\end{array}$ & 58 & 77.3 & 17 & 22.7 & 42 & 56 & 33 & 44 & $\begin{array}{c}7.680 \\
0.006 * \\
\end{array}$ & $\begin{array}{l}0.366 \\
0.545 \\
\end{array}$ & $\begin{array}{l}0.246 \\
0.620 \\
\end{array}$ \\
\hline
\end{tabular}

*Significance at level $\mathrm{P}<0.05$ 
Table (3) percentage distribution of the study and control groups practice regarding assessment signs and symptoms indicating upper airway secretion during oropharyngeal and nasopharyngeal suction immediately and 2 weeks following teaching intervention.

\begin{tabular}{|c|c|c|c|c|c|c|c|c|c|c|c|c|c|c|c|c|c|c|c|c|}
\hline \multirow{4}{*}{$\begin{array}{l}\text { Students practice before } \\
\text { oropharyngeal and } \\
\text { nasopharyngeal suction }\end{array}$} & \multicolumn{9}{|c|}{ Immediately after the teaching intervention } & \multicolumn{9}{|c|}{$\begin{array}{l}2 \text { weeks after } \\
\text { the teaching intervention }\end{array}$} & P1\&P2 & P1\&P2 \\
\hline & \multicolumn{4}{|c|}{ Study group } & \multicolumn{4}{|c|}{ Control group } & \multirow{3}{*}{$\begin{array}{c}\text { Chi } \\
\text { p-value }\end{array}$} & \multicolumn{4}{|c|}{ Study group } & \multicolumn{4}{|c|}{ Control group } & \multirow{3}{*}{$\begin{array}{c}\text { Chi } \\
\text { p-value }\end{array}$} & \multirow{2}{*}{$\begin{array}{l}\text { Study } \\
\text { group }\end{array}$} & \multirow{2}{*}{$\begin{array}{l}\text { Contro } \\
1 \\
\text { group }\end{array}$} \\
\hline & \multicolumn{2}{|c|}{ Correct } & \multicolumn{2}{|c|}{ Incorrect } & \multicolumn{2}{|c|}{ Correct } & \multicolumn{2}{|c|}{ Incorrect } & & \multicolumn{2}{|c|}{ Correct } & \multicolumn{2}{|c|}{ Incorrect } & \multicolumn{2}{|c|}{ Correct } & \multicolumn{2}{|c|}{ Incorrect } & & & \\
\hline & No. & $\%$ & No & $\%$ & No. & $\%$ & No. & $\%$ & & No. & $\%$ & No. & $\%$ & No. & $\%$ & No. & $\%$ & & $\begin{array}{c}\text { Chi } \\
\text { p-value }\end{array}$ & $\begin{array}{l}\text { Chi } \\
\text { p- } \\
\text { value }\end{array}$ \\
\hline
\end{tabular}

Assessment signs \&symptoms indicating upper airway secretions

\begin{tabular}{|c|c|c|c|c|c|c|c|c|c|c|c|c|c|c|c|c|c|c|c|c|}
\hline $\begin{array}{l}\text { Assess patient } \\
\text { restlessness }\end{array}$ & 59 & 78.7 & 16 & 21.3 & 57 & 24 & 18 & 76 & $\begin{array}{l}0.152 \\
0.697\end{array}$ & 56 & 74.7 & 19 & 25.3 & 62 & 82.7 & 13 & 17.3 & $\begin{array}{l}1.430 \\
0.232\end{array}$ & $\begin{array}{l}0.335 \\
0.562\end{array}$ & $\begin{array}{l}1.017 \\
0.313\end{array}$ \\
\hline $\begin{array}{c}\text { Auscultate gurgling } \\
\text { sound during respiration }\end{array}$ & 66 & 88 & 9 & 12 & 66 & 88 & 9 & 12 & $\begin{array}{l}0.001 \\
1.000\end{array}$ & 63 & 84 & 12 & 16 & 52 & 69.3 & 23 & 30.7 & $\begin{array}{l}0.609 \\
0.435\end{array}$ & $\begin{array}{l}0.498 \\
0.480\end{array}$ & $\begin{array}{l}7.786 \\
0.005 *\end{array}$ \\
\hline $\begin{array}{l}\text { Observe patient skin } \\
\text { color }\end{array}$ & 54 & 72 & 21 & 28 & 48 & 64 & 27 & 36 & $\begin{array}{l}1.103 \\
0.294\end{array}$ & 53 & 70.7 & 22 & 29.3 & 37 & 49.3 & 38 & 50.7 & $\begin{array}{c}7.111 \\
0.008 *\end{array}$ & $\begin{array}{l}0.033 \\
0.857\end{array}$ & $\begin{array}{l}3.285 \\
0.070\end{array}$ \\
\hline $\begin{array}{c}\text { Check respiration } \\
\text { \&auscultate lung sound }\end{array}$ & 60 & 80 & 15 & 20 & 60 & 80 & 15 & 20 & $\begin{array}{l}0.001 \\
1.000\end{array}$ & 60 & 80 & 15 & 20 & 34 & 45.3 & 41 & 54.7 & $\begin{array}{l}19.263 \\
0.000 * *\end{array}$ & $\begin{array}{l}0.000 \\
1.000\end{array}$ & $\begin{array}{c}19.263 \\
0.000 * \\
*\end{array}$ \\
\hline Check vital signs & 67 & 89.3 & 8 & 10.7 & 69 & 92 & 6 & 8 & $\begin{array}{l}0.315 \\
0.575\end{array}$ & 63 & 84 & 12 & 16 & 37 & 49.3 & 38 & 50.7 & $\begin{array}{c}20.280 \\
0.000 * *\end{array}$ & $\begin{array}{l}0.923 \\
0.337\end{array}$ & $\begin{array}{c}\mathbf{3 2 . 9 3 3} \\
\mathbf{0 . 0 0 0} \\
*\end{array}$ \\
\hline $\begin{array}{c}\text { Determine decreased } \\
\text { oxygen saturation }\end{array}$ & 59 & 78.7 & 16 & 21.3 & 57 & 76 & 18 & 24 & $\begin{array}{l}0.152 \\
0.697\end{array}$ & 57 & 76 & 18 & 24 & 23 & 30.7 & 52 & 69.3 & $\begin{array}{c}30.964 \\
0.000^{* *}\end{array}$ & $\begin{array}{l}0.152 \\
0.697\end{array}$ & $\begin{array}{c}30.964 \\
0.000 * \\
*\end{array}$ \\
\hline Total & 365 & 81.1 & 85 & 18.9 & 357 & 79.3 & 93 & 20.7 & $\begin{array}{l}0.448 \\
0.503\end{array}$ & 352 & 78.2 & 98 & 21.8 & 245 & 54.4 & 205 & 45.6 & $\begin{array}{c}56.963 \\
0.000 * *\end{array}$ & $\begin{array}{l}1.159 \\
0.282\end{array}$ & \\
\hline
\end{tabular}

*Significanceat level $\mathrm{P}<0.05$ 
Table (4) percentage distribution of the study and control groups practice regarding intervention and implementation of airway suction during oropharyngeal and nasopharyngeal suction immediately and 2 weeks following teaching intervention.

\begin{tabular}{|c|c|c|c|c|c|c|c|c|c|c|c|c|c|c|c|c|c|c|c|c|}
\hline \multirow{4}{*}{$\begin{array}{l}\text { Students practice during } \\
\text { oropharyngeal and } \\
\text { nasopharyngeal suction }\end{array}$} & \multicolumn{9}{|c|}{ Immediately after the teaching intervention } & \multicolumn{9}{|c|}{$\begin{array}{l}2 \text { weeks after } \\
\text { the teaching intervention }\end{array}$} & P3\&P4 & P3\&P4 \\
\hline & \multicolumn{4}{|c|}{$\begin{array}{l}\text { Study group } \\
(\mathrm{n}=\mathbf{7 5})\end{array}$} & \multicolumn{4}{|c|}{$\underset{(n=75)}{\text { Control group }}$} & \multirow{3}{*}{$\begin{array}{c}\text { Chi } \\
\text { p- } \\
\text { value }\end{array}$} & \multicolumn{4}{|c|}{$\begin{array}{l}\text { Study group } \\
(\mathrm{n}=\mathbf{7 5})\end{array}$} & \multicolumn{4}{|c|}{$\begin{array}{c}\text { Control group } \\
(\mathrm{n}=75)\end{array}$} & \multirow{3}{*}{$\underset{\text { p-value }}{\text { Chi }}$} & \multirow{2}{*}{$\begin{array}{l}\text { Study } \\
\text { group }\end{array}$} & \multirow{2}{*}{$\begin{array}{l}\text { Contro } \\
\text { l group }\end{array}$} \\
\hline & \multicolumn{2}{|c|}{ Correct } & \multicolumn{2}{|c|}{ Incorrect } & \multicolumn{2}{|c|}{ Correct } & \multicolumn{2}{|c|}{ Incorrect } & & \multicolumn{2}{|c|}{ Correct } & \multicolumn{2}{|c|}{ Incorrect } & \multicolumn{2}{|c|}{ Correct } & \multicolumn{2}{|c|}{ Incorrect } & & & \\
\hline & No. & $\%$ & No & $\%$ & No. & $\%$ & No. & $\%$ & & No. & $\%$ & No. & $\%$ & No. & $\%$ & No. & $\%$ & & $\begin{array}{c}\text { Chi } \\
\text { p-value }\end{array}$ & $\begin{array}{c}\text { Chi } \\
\text { p-value }\end{array}$ \\
\hline
\end{tabular}

Intervention and implementation for suctioning

\begin{tabular}{|c|c|c|c|c|c|c|c|c|c|c|c|c|c|c|c|c|c|c|c|c|}
\hline Perform hand hygiene & 61 & 81.3 & 14 & 18.7 & 61 & 81.3 & 14 & 18.7 & $\begin{array}{l}0.001 \\
1.000\end{array}$ & 61 & 81.3 & 14 & 18.7 & 27 & 64 & 48 & 36 & $\begin{array}{l}31.782 \\
0.000^{* * *}\end{array}$ & $\begin{array}{l}0.000 \\
1.000\end{array}$ & $\begin{array}{c}31.7 \\
82 \\
0.00 \\
0 * * \\
\end{array}$ \\
\hline $\begin{array}{l}\text { Place a towel across the } \\
\text { child's chest }\end{array}$ & 58 & 77.3 & 17 & 22.7 & 54 & 72 & 21 & 28 & $\begin{array}{l}0.564 \\
0.453\end{array}$ & 58 & 77.3 & 17 & 22.7 & 27 & 36 & 48 & 64 & $\begin{array}{l}26.090 \\
0.000 * *\end{array}$ & $\begin{array}{l}0.000 \\
1.000\end{array}$ & $\begin{array}{c}19.5 \\
65 \\
0.00 \\
0 * *\end{array}$ \\
\hline $\begin{array}{l}\text { Turn suction to } \\
\text { appropriate pressure }\end{array}$ & 62 & 82.7 & 13 & 17.3 & 60 & 80 & 15 & 20 & $\begin{array}{l}0.176 \\
0.675\end{array}$ & 62 & 82.7 & 13 & 17.3 & 41 & 54.7 & 34 & 45.3 & $\begin{array}{l}13.665 \\
0.000^{* * *}\end{array}$ & $\begin{array}{l}0.000 \\
1.000\end{array}$ & $\begin{array}{c}10.9 \\
42 \\
0.00 \\
1^{*} \\
\end{array}$ \\
\hline $\begin{array}{l}\text { Open sterile catheter } \\
\text { package on a clean }\end{array}$ & 54 & 72 & 21 & 28 & 49 & 65.3 & 26 & 34.7 & $\begin{array}{l}0.775 \\
0.379\end{array}$ & 54 & 72 & 21 & 28 & 21 & 28 & 54 & 72 & $\begin{array}{l}29.040 \\
0.000 * *\end{array}$ & $\begin{array}{l}0.000 \\
1.000\end{array}$ & $\begin{array}{c}21.0 \\
00 \\
0.00 \\
0^{* *}\end{array}$ \\
\hline $\begin{array}{l}\text { Connect it to the suction } \\
\text { machine tube }\end{array}$ & 59 & 78.7 & 16 & 21.3 & 57 & 76 & 18 & 24 & $\begin{array}{l}\mathbf{0 . 1 5 2} \\
\mathbf{0 . 6 9 7}\end{array}$ & 59 & 78.7 & 16 & 21.3 & 59 & 78.7 & 16 & 21.3 & $\begin{array}{l}0.001 \\
1.000\end{array}$ & $\begin{array}{l}0.000 \\
1.000\end{array}$ & $\begin{array}{c}0.15 \\
2 \\
0.69 \\
7 \\
\end{array}$ \\
\hline $\begin{array}{l}\text { Hyperventilate the } \\
\text { patient with several } \\
\text { breathes }\end{array}$ & 48 & 64 & 27 & 36 & 32 & 42.7 & 43 & 57.3 & $\begin{array}{c}6.857 \\
0.009 *\end{array}$ & 48 & 64 & 27 & 36 & 32 & 42.7 & 43 & 57.3 & $\begin{array}{c}6.857 \\
0.009 *\end{array}$ & $\begin{array}{l}0.000 \\
1.000\end{array}$ & $\begin{array}{c}\mathbf{0 . 0 0} \\
0 \\
1.00 \\
0\end{array}$ \\
\hline
\end{tabular}




\section{Continue table (4)}

\begin{tabular}{|c|c|c|c|c|c|c|c|c|c|c|c|c|c|c|c|c|c|c|c|c|}
\hline $\begin{array}{l}\text { Wear a clean disposable } \\
\text { gloves in non-dominant } \\
\text { hand and one sterile in } \\
\text { dominant hand }\end{array}$ & 53 & 70.7 & 22 & 29.3 & 45 & 60 & 30 & 40 & $\begin{array}{l}1.884 \\
0.170\end{array}$ & 53 & 70.7 & 22 & 29.3 & 34 & 45.3 & 41 & 54.7 & $\begin{array}{l}9.880 \\
0.002 *\end{array}$ & $\begin{array}{l}0.000 \\
1.000\end{array}$ & $\begin{array}{l}3.236 \\
0.072\end{array}$ \\
\hline $\begin{array}{l}\text { Check the equipment } \\
\text { functioning properly }\end{array}$ & 62 & 82.7 & 13 & 17.3 & 58 & 77.3 & 17 & 22.7 & $\begin{array}{l}0.667 \\
0.414\end{array}$ & 62 & 82.7 & 13 & 17.3 & 41 & 54.7 & 34 & 45.3 & $\begin{array}{l}13.665 \\
0.000 * \\
*\end{array}$ & $\begin{array}{l}0.000 \\
1.000\end{array}$ & $\begin{array}{l}8.586 \\
0.003 *\end{array}$ \\
\hline $\begin{array}{l}\text { Turn off the suction } \\
\text { apparatus }\end{array}$ & 55 & 73.3 & 20 & 26.7 & 52 & 69.3 & 23 & 30.7 & $\begin{array}{l}0.293 \\
0.588\end{array}$ & 55 & 73.3 & 20 & 26.7 & 66 & 88 & 9 & 12 & $\begin{array}{c}5.172 \\
0.023 *\end{array}$ & $\begin{array}{l}0.000 \\
1.000\end{array}$ & $\begin{array}{l}7.786 \\
0.005^{*}\end{array}$ \\
\hline $\begin{array}{l}\text { Insert catheter into the } \\
\text { tracheal tube gently and } \\
\text { quickly until resistance } \\
\text { is met then put it } \\
\text { back. } 5 \mathrm{~cm}\end{array}$ & 67 & 89.3 & 8 & 10.7 & 63 & 84 & 12 & 16 & $\begin{array}{l}\mathbf{0 . 9 2 3} \\
\mathbf{0 . 3 3 7}\end{array}$ & 67 & 89.3 & 8 & 10.7 & 56 & 74.7 & 19 & 25.3 & $\begin{array}{c}5.465 \\
0.019 *\end{array}$ & $\begin{array}{l}0.000 \\
1.000\end{array}$ & $\begin{array}{l}1.992 \\
0.158\end{array}$ \\
\hline $\begin{array}{l}\text { Turn suction to } \\
\text { appropriate pressure }\end{array}$ & 55 & 73.3 & 20 & 26.7 & 48 & 61 & 27 & 36 & $\begin{array}{l}1.518 \\
0.218\end{array}$ & 55 & 73.3 & 20 & 26.7 & 41 & 54.7 & 34 & 45.3 & $\begin{array}{c}5.671 \\
0.017^{*}\end{array}$ & $\begin{array}{l}0.000 \\
1.000\end{array}$ & $\begin{array}{l}1.354 \\
0.245\end{array}$ \\
\hline $\begin{array}{l}\text { Rotate catheter gently } \\
\text { in one smooth un } \\
\text { interrupted motion }\end{array}$ & 71 & 94.7 & 4 & 5.3 & 69 & 92 & 6 & 8 & $\begin{array}{l}0.429 \\
0.513\end{array}$ & 71 & 94.7 & 4 & 5.3 & 46 & 61.3 & 29 & 38.7 & $\begin{array}{l}24.281 \\
0.000 * \\
*\end{array}$ & $\begin{array}{l}0.000 \\
1.000\end{array}$ & $\begin{array}{c}19.714 \\
0.000^{* * *}\end{array}$ \\
\hline $\begin{array}{l}\text { Provide hyper } \\
\text { ventilation in between } \\
\text { and after suctioning }\end{array}$ & 64 & 14.7 & 11 & 14.7 & 64 & 85.3 & 11 & 14.7 & $\begin{array}{l}0.001 \\
1.000\end{array}$ & 64 & 14.7 & 11 & 14.7 & 29 & 38.7 & 46 & 61.7 & $\begin{array}{c}34.663 \\
0.000 * \\
*\end{array}$ & $\begin{array}{l}0.000 \\
1.000\end{array}$ & $\begin{array}{c}34.663 \\
0.000^{* * *}\end{array}$ \\
\hline $\begin{array}{l}\text { Allow patient to rest 2-3 } \\
\text { minutes in between } \\
\text { suctioning }\end{array}$ & 65 & 86.7 & 10 & 13.3 & 63 & 84 & 12 & 16 & $\begin{array}{l}0.213 \\
0.644\end{array}$ & 65 & 86.7 & 10 & 13.3 & 36 & 48 & 39 & 52 & $\begin{array}{c}25.490 \\
0.000 * \\
*\end{array}$ & $\begin{array}{l}0.000 \\
1.000\end{array}$ & $\begin{array}{l}21.658 \\
0.000 * *\end{array}$ \\
\hline
\end{tabular}


Tanta Scientific Nursing Journal

\section{Continue table (4)}

\begin{tabular}{|c|c|c|c|c|c|c|c|c|c|c|c|c|c|c|c|c|c|c|c|c|}
\hline $\begin{array}{l}\text { Assess patient cardio } \\
\text { pulmonary status in } \\
\text { between suction }\end{array}$ & 54 & 72 & 21 & 28 & 54 & 72 & 21 & 28 & $\begin{array}{l}0.001 \\
1.000\end{array}$ & 54 & 72 & 21 & 28 & 45 & 60 & 30 & 40 & $\begin{array}{l}2.406 \\
0.121\end{array}$ & $\begin{array}{l}0.000 \\
1.000\end{array}$ & $\begin{array}{l}2.406 \\
0.121\end{array}$ \\
\hline $\begin{array}{l}\text { Flush the catheter } \\
\text { with sterile water or } \\
\text { normal saline }\end{array}$ & 62 & 82.7 & 13 & 17.3 & 60 & 80 & 15 & 20 & $\begin{array}{l}0.176 \\
0.675\end{array}$ & 62 & 82.7 & 13 & 17.3 & 61 & 81.3 & 14 & 18.7 & $\begin{array}{l}\mathbf{0 . 0 4 5} \\
\mathbf{0 . 8 3 2}\end{array}$ & $\begin{array}{l}0.000 \\
1.000\end{array}$ & $\begin{array}{l}0.043 \\
0.836\end{array}$ \\
\hline $\begin{array}{l}\text { Repeat suctioning as } \\
\text { needed }\end{array}$ & 64 & 85.3 & 11 & 14.7 & 61 & 81.3 & 14 & 18.7 & $\begin{array}{l}0.432 \\
0.511\end{array}$ & 64 & 85.3 & 11 & 14.7 & 65 & 86.7 & 10 & 13.3 & $\begin{array}{l}0.055 \\
0.814\end{array}$ & $\begin{array}{l}0.000 \\
1.000\end{array}$ & $\begin{array}{l}0.794 \\
0.373\end{array}$ \\
\hline TOTAL & $\begin{array}{l}10 \\
14\end{array}$ & 79.5 & 261 & 20.5 & 950 & 74.5 & 325 & 25.5 & $\begin{array}{l}9.075 \\
\mathbf{0 . 0 0 3} \\
*\end{array}$ & $\begin{array}{c}101 \\
4 \\
\end{array}$ & 79.5 & 261 & 20.5 & 727 & 57 & 548 & 43 & $\begin{array}{l}149.127 \\
0.000 * *\end{array}$ & $\begin{array}{l}0.001 \\
1.000\end{array}$ & $\begin{array}{c}86.61 \\
7 \\
0.000 \\
* * \\
\end{array}$ \\
\hline
\end{tabular}

*Significanceat level P $<0.05$ 
Table (5) percentage distribution of the study and control groups practice regarding post care after airway suction during endotracheal and tracheostomy suction immediately after and 2 weeks following teaching interventions.

\begin{tabular}{|c|c|c|c|c|c|c|c|c|c|c|c|c|c|c|c|c|c|c|c|c|}
\hline \multirow{4}{*}{$\begin{array}{c}\text { Students practice after } \\
\text { endotracheal and } \\
\text { tracheostomy } \\
\text { suction. }\end{array}$} & \multicolumn{9}{|c|}{ Immediately after the teaching intervention } & \multicolumn{9}{|c|}{ 2weeks after the teaching intervention } & P2\&P3 & P2\&P3 \\
\hline & \multicolumn{4}{|c|}{$\begin{array}{c}\text { Study group } \\
\quad(n=75)\end{array}$} & \multicolumn{4}{|c|}{$\begin{array}{c}\text { Control group } \\
(n=75)\end{array}$} & \multirow{3}{*}{$\begin{array}{c}\text { Chi } \\
\text { p-value }\end{array}$} & \multicolumn{4}{|c|}{$\begin{array}{c}\text { Study group } \\
\quad(n=75)\end{array}$} & \multicolumn{4}{|c|}{$\begin{array}{c}\text { Control group } \\
(n=75)\end{array}$} & \multirow{3}{*}{$\underset{\text { p-value }}{\text { Chi }}$} & \multirow{2}{*}{$\begin{array}{l}\text { Study } \\
\text { group }\end{array}$} & \multirow{2}{*}{$\begin{array}{l}\text { Contro } \\
1 \text { group }\end{array}$} \\
\hline & \multicolumn{2}{|c|}{ Correct } & \multicolumn{2}{|c|}{ Incorrect } & \multicolumn{2}{|c|}{ Correct } & \multicolumn{2}{|c|}{ Incorrect } & & \multicolumn{2}{|c|}{ Correct } & \multicolumn{2}{|c|}{ Incorrect } & \multicolumn{2}{|c|}{ Correct } & \multicolumn{2}{|c|}{ Incorrect } & & & \\
\hline & No. & $\%$ & No & $\%$ & No. & $\%$ & No. & $\%$ & & No. & $\%$ & No. & $\%$ & No. & $\%$ & No. & $\%$ & & $\begin{array}{c}\text { Chi } \\
\text { p-value }\end{array}$ & $\begin{array}{c}\text { Chi } \\
\text { p-value }\end{array}$ \\
\hline
\end{tabular}

Postcare

\begin{tabular}{|c|c|c|c|c|c|c|c|c|c|c|c|c|c|c|c|c|c|c|c|c|}
\hline $\begin{array}{l}\text { reassess the patient } \\
\text { respiratory status, } \\
\text { pulse oximatery and } \\
\text { observe the patient for } \\
\text { vital signs, cyanosis } \\
\text { and restlessness }\end{array}$ & 64 & 85.3 & 11 & 14.7 & 55 & 73.3 & 20 & 26.7 & $\begin{array}{l}3.294 \\
0.070\end{array}$ & 59 & 78.7 & 16 & 21.3 & 27 & 36 & 48 & 64 & $\begin{array}{l}27.907 \\
0.000 * *\end{array}$ & $\begin{array}{l}1.129 \\
0.288\end{array}$ & $\begin{array}{l}21.090 \\
0.000^{* *}\end{array}$ \\
\hline $\begin{array}{l}\text { Comfort and reassure } \\
\text { the patient }\end{array}$ & 67 & 89.3 & 8 & 10.3 & 61 & 81.3 & 14 & 18.7 & $\begin{array}{l}1.918 \\
0.166\end{array}$ & 63 & 84 & 12 & 16 & 41 & 54.7 & 34 & 45.3 & $\begin{array}{l}15.176 \\
0.000^{* *}\end{array}$ & $\begin{array}{l}0.923 \\
0.337\end{array}$ & $\begin{array}{l}12.255 \\
0.000^{* *}\end{array}$ \\
\hline Return the equipment & 67 & 89.3 & 8 & 10.3 & 66 & 88 & 9 & 12 & $\begin{array}{l}0.066 \\
0.797\end{array}$ & 75 & 100 & $\mathbf{0}$ & $\mathbf{0}$ & 63 & 84 & 12 & 16 & $\begin{array}{l}13.043 \\
0.000 * *\end{array}$ & $\begin{array}{l}0.923 \\
0.337\end{array}$ & $\begin{array}{l}9.574 \\
0.002 *\end{array}$ \\
\hline Remove gloves & 63 & 84 & 12 & 16 & 55 & 73.3 & 20 & 26.7 & $\begin{array}{l}2.542 \\
0.111\end{array}$ & 75 & 100 & $\mathbf{0}$ & $\mathbf{0}$ & 63 & 84 & 12 & 16 & $\begin{array}{l}13.043 \\
0.000^{* *}\end{array}$ & $\begin{array}{l}0.000 \\
1.000\end{array}$ & $\begin{array}{l}23.077 \\
\mathbf{0 . 0 0 0}^{* *}\end{array}$ \\
\hline Wash hands & 61 & 81.3 & 14 & 18.7 & 43 & 57.3 & 32 & 42.7 & $\begin{array}{l}10.159 \\
0.000^{* *}\end{array}$ & 75 & 100 & $\mathbf{0}$ & $\mathbf{0}$ & 61 & 81.3 & 14 & 18.7 & $\begin{array}{c}15.441 \\
0.000 * *\end{array}$ & $\begin{array}{l}0.000 \\
1.000 \\
\end{array}$ & $\begin{array}{l}40.678 \\
0.000^{* *}\end{array}$ \\
\hline TOTAL & 322 & 85.9 & 53 & 14.1 & 280 & 74.7 & 95 & 25.3 & $\begin{array}{c}14.849 \\
0.000^{* *}\end{array}$ & 347 & 92.5 & 28 & 7.5 & 225 & 68 & 120 & 32 & $\begin{array}{c}82.103 \\
0.000^{* *}\end{array}$ & $\begin{array}{l}1.688 \\
0.194\end{array}$ & $\begin{array}{l}1.250 \\
0.264\end{array}$ \\
\hline
\end{tabular}

*Significanceat level $\mathrm{P}<0.05$ 
Table (6) percentage distribution of the study and control groups practice regarding documentation after airway suction during endotracheal and tracheostomy suction immediately after and 2 weeks following teaching interventions.

\begin{tabular}{|c|c|c|c|c|c|c|c|c|c|c|c|c|c|c|c|c|c|c|c|c|}
\hline \multirow{4}{*}{$\begin{array}{c}\text { Students practice } \\
\text { before endotracheal } \\
\text { and tracheostomy } \\
\text { suction. }\end{array}$} & \multicolumn{9}{|c|}{ Immediately after the teaching intervention } & \multicolumn{9}{|c|}{2 weeks after the teaching intervention } & \multirow{4}{*}{$\begin{array}{c}\text { P2\&P3 } \\
\begin{array}{c}\text { Study } \\
\text { group }\end{array} \\
\begin{array}{c}\text { Chi } \\
\text { p-value }\end{array}\end{array}$} & \multirow{4}{*}{$\begin{array}{c}\text { P2\&P3 } \\
\begin{array}{c}\text { Control } \\
\text { group }\end{array} \\
\begin{array}{c}\text { Chi } \\
\text { p-value }\end{array}\end{array}$} \\
\hline & \multicolumn{4}{|c|}{$\begin{array}{c}\begin{array}{c}\text { Study group } \\
(\mathrm{n}=75)\end{array} \\
\end{array}$} & \multicolumn{4}{|c|}{$\begin{array}{c}\text { Control group } \\
(n=75)\end{array}$} & \multirow{3}{*}{$\begin{array}{c}\text { Chi } \\
\text { p-value }\end{array}$} & \multicolumn{4}{|c|}{$\begin{array}{c} \\
\text { Study group } \\
(n=75)\end{array}$} & \multicolumn{4}{|c|}{$\begin{array}{c}\text { Control group } \\
(\mathrm{n}=75)\end{array}$} & \multirow{3}{*}{$\begin{array}{c}\text { Chi } \\
\text { p-value }\end{array}$} & & \\
\hline & \multicolumn{2}{|c|}{ Correct } & \multicolumn{2}{|c|}{ Incorrect } & \multicolumn{2}{|c|}{ Correct } & \multicolumn{2}{|c|}{ Incorrect } & & \multicolumn{2}{|c|}{ Correct } & \multicolumn{2}{|c|}{ Incorrect } & \multicolumn{2}{|c|}{ Correct } & \multicolumn{2}{|c|}{ Incorrect } & & & \\
\hline & No. & $\%$ & No & $\%$ & No. & $\%$ & No. & $\%$ & & No. & $\%$ & No. & $\%$ & No. & $\%$ & No. & $\%$ & & & \\
\hline \multicolumn{21}{|l|}{ Documentation } \\
\hline Indication for suction & 62 & 82.7 & 13 & $\mathbf{1 7 . 3}$ & 55 & 73.3 & 20 & 26.7 & $\begin{array}{l}1.904 \\
0.168\end{array}$ & 59 & 78.7 & 16 & 21.3 & 44 & 58.7 & 31 & 41.3 & $\begin{array}{l}6.972 \\
0.008 *\end{array}$ & $\begin{array}{l}\mathbf{0 . 3 8 5} \\
\mathbf{0 . 5 3 5}\end{array}$ & $\begin{array}{l}3.595 \\
\mathbf{0 . 0 5 8}\end{array}$ \\
\hline $\begin{array}{l}\text { Record vital signs } \\
\text { before and after }\end{array}$ & 57 & 76 & 18 & 24 & 49 & 65.3 & 26 & 34.7 & $\begin{array}{l}2.058 \\
\mathbf{0 . 1 5 1}\end{array}$ & 57 & 76 & 18 & 24 & 38 & 50.7 & 37 & 49.3 & $\begin{array}{l}10.364 \\
0.001 *\end{array}$ & $\begin{array}{l}0.000 \\
1.000\end{array}$ & $\begin{array}{l}3.311 \\
0.069\end{array}$ \\
\hline $\begin{array}{l}\text { Pressure delivered for } \\
\text { suction }\end{array}$ & 45 & 60 & 30 & 40 & 43 & $\mathbf{5 7 . 3}$ & 32 & 42.7 & $\begin{array}{l}\mathbf{0 . 1 1 0} \\
\mathbf{0 . 7 4 0}\end{array}$ & 45 & 60 & 30 & 40 & 28 & 37.3 & 47 & 62.7 & $\begin{array}{l}7.712 \\
0.005^{*}\end{array}$ & $\begin{array}{l}0.000 \\
1.000\end{array}$ & $\begin{array}{c}6.017 \\
0.014 *\end{array}$ \\
\hline $\begin{array}{l}\text { Color, amount, } \\
\text { consistency and Odor } \\
\text { of secretion }\end{array}$ & 60 & 80 & 15 & 40 & 51 & 68 & 24 & 32 & $\begin{array}{l}2.807 \\
0.094\end{array}$ & 56 & 74.7 & 19 & 25.3 & 53 & 70.7 & 22 & 29.3 & $\begin{array}{l}0.302 \\
0.583\end{array}$ & $\begin{array}{l}0.609 \\
0.435\end{array}$ & $\begin{array}{l}\mathbf{0 . 1 2 5} \\
\mathbf{0 . 7 2 3}\end{array}$ \\
\hline Frequency of suction & 57 & 76 & 18 & 24 & 53 & 70.7 & 22 & 29.3 & $\begin{array}{l}0.545 \\
0.460\end{array}$ & 55 & 73.3 & 20 & 26.7 & 18 & 24 & 57 & 76 & $\begin{array}{c}\mathbf{3 6 . 5 3 3} \\
\mathbf{0 . 0 0 0 * *}\end{array}$ & $\begin{array}{l}0.141 \\
0.707\end{array}$ & $\begin{array}{l}32.760 \\
0.000 * *\end{array}$ \\
\hline Date and time & 63 & 84 & 12 & 16 & 52 & 69.3 & 23 & 30.7 & $\begin{array}{l}4.509 \\
0.034 \\
*\end{array}$ & 60 & 80 & 15 & 20 & 53 & 70.7 & 22 & 29.3 & $\begin{array}{l}1.758 \\
0.185\end{array}$ & $\begin{array}{l}\mathbf{0 . 4 0 7} \\
\mathbf{0 . 5 2 4}\end{array}$ & $\begin{array}{l}\mathbf{0 . 0 3 2} \\
\mathbf{0 . 8 5 9}\end{array}$ \\
\hline ABGs available & 61 & 81.3 & 14 & 18.7 & 60 & 80 & 15 & 20 & $\begin{array}{l}0.043 \\
0.836\end{array}$ & 58 & 77.3 & 17 & 22.7 & 21 & 28 & 54 & 72 & $\begin{array}{c}36.611 \\
0.000 * *\end{array}$ & $\begin{array}{l}0.366 \\
0.545\end{array}$ & $\begin{array}{c}40.821 \\
0.000 * *\end{array}$ \\
\hline $\begin{array}{l}\text { Presence of any } \\
\text { complication }\end{array}$ & 60 & 80 & 15 & 20 & 49 & 65.3 & 26 & 34.7 & $\begin{array}{c}4.061 \\
0.044 \\
*\end{array}$ & 52 & 69.3 & 23 & 30.7 & 21 & 28 & 54 & 72 & $\begin{array}{c}25.645 \\
0.000^{* *}\end{array}$ & $\begin{array}{l}2.256 \\
\mathbf{0 . 1 3 3}\end{array}$ & $\begin{array}{r}21.000 \\
0.000 * *\end{array}$ \\
\hline TOTAL & 465 & 77.5 & 135 & 22.5 & 412 & 68.7 & 188 & 31.3 & $\begin{array}{l}11.900 \\
0.001 *\end{array}$ & 442 & 73.7 & 158 & 26.3 & 276 & 46 & 324 & 54 & $\begin{array}{c}95.549 \\
0.000^{* *}\end{array}$ & $\begin{array}{l}2.389 \\
0.122\end{array}$ & $\begin{array}{c}63.009 \\
0.000 * *\end{array}$ \\
\hline
\end{tabular}

*Significanceat level $\mathrm{P}<0.05$ 
Table (7): The total score of the students' knowledge regarding airway suction

\begin{tabular}{|c|c|c|c|c|c|c|c|c|c|c|c|c|c|c|c|c|}
\hline \multirow{3}{*}{ Tool 1} & \multicolumn{4}{|c|}{$\begin{array}{c}\text { Before } \\
\text { the program }\end{array}$} & \multicolumn{4}{|c|}{$\begin{array}{c}\text { Immediately after } \\
\text { the program }\end{array}$} & \multicolumn{4}{|c|}{$\begin{array}{l}2 \text { Weeks after } \\
\text { the program }\end{array}$} & \multicolumn{4}{|c|}{$\begin{array}{l}8 \text { Weeks after } \\
\text { the program }\end{array}$} \\
\hline & \multicolumn{2}{|c|}{ Satisfactory } & \multicolumn{2}{|c|}{ Un Satisfactory } & \multicolumn{2}{|c|}{ Satisfactory } & \multicolumn{2}{|c|}{$\begin{array}{c}\text { Un } \\
\text { Satisfactory }\end{array}$} & \multicolumn{2}{|c|}{ Satisfactory } & \multicolumn{2}{|c|}{ Un Satisfactory } & \multicolumn{2}{|c|}{ Satisfactory } & \multicolumn{2}{|c|}{ Un Satisfactory } \\
\hline & No. & $\%$ & No & $\%$ & No. & $\%$ & No. & $\%$ & No. & $\%$ & No. & $\%$ & No. & $\%$ & No. & $\%$ \\
\hline study & 4 & 5.3 & 71 & 94.7 & 74 & 98.7 & 1 & 1.3 & 74 & 98.7 & 1 & 1.3 & 74 & 98.7 & 1 & 1.3 \\
\hline control & 10 & 13.3 & 65 & 86.7 & 69 & 92 & 6 & 8 & 50 & 66.7 & 25 & 33.3 & 44 & 58.7 & 31 & 41.3 \\
\hline
\end{tabular}

Table (8): The total score of the students' performance regarding airway suction

\begin{tabular}{|c|c|c|c|c|c|c|c|c|c|c|c|c|}
\hline \multirow{3}{*}{ Tool 2} & \multicolumn{4}{|c|}{$\begin{array}{l}\text { Immediately after } \\
\text { the program }\end{array}$} & \multicolumn{4}{|c|}{$\begin{array}{l}2 \text { Weeks after } \\
\text { the program }\end{array}$} & \multicolumn{4}{|c|}{$\begin{array}{c}8 \text { Weeks after } \\
\text { the program }\end{array}$} \\
\hline & \multicolumn{2}{|c|}{ Satisfactory } & \multicolumn{2}{|c|}{$\begin{array}{c}\text { Un } \\
\text { Satisfactory }\end{array}$} & \multicolumn{2}{|c|}{ Satisfactory } & \multicolumn{2}{|c|}{$\begin{array}{c}\text { Un } \\
\text { Satisfactory }\end{array}$} & \multicolumn{2}{|c|}{ Satisfactory } & \multicolumn{2}{|c|}{ Un Satisfactory } \\
\hline & No. & $\%$ & No. & $\%$ & No. & $\%$ & No. & $\%$ & No. & $\%$ & No. & $\%$ \\
\hline Study & 70 & 93.3 & 5 & 6.7 & 68 & 90.7 & 7 & 9.3 & 67 & 89.3 & 8 & 10.7 \\
\hline Control & 60 & 80 & 15 & 20 & 25 & 33.3 & 50 & 66.7 & 17 & 22.7 & 58 & 77.3 \\
\hline
\end{tabular}




\section{Discussion:}

The use of technology in education provides the students with the most suitable environment to learn, serves to create interest and learning centered atmosphere, and helps increase the students' motivation. The use of technology in this way plays an important role in the teaching and learning process. The use of computers in the teaching and learning is defined as computer based instruction $^{(2)}$.

The computer based instruction makes teaching techniques far more effective than those of the traditional teaching method as it used for presenting information, testing and evaluation and providing feedback. It makes a contribution to the individualization of education. It motivates students and takes them to take an active part in the learning process. It helps to develop creativity and problem solving skills, identity and self-reliance in learners. Computer based instruction provides drawings, graphics, animation, music and plenty materials for the students to proceed at their own pace and in line with their individual differences. It serves to control lots of variables having an impact on learning, which cannot be controlled by means of traditional educational techniques ${ }^{(26,27)}$.
Activities that the graduate of the baccalaureate programs in nursing is to do, provide an integrated program of theoretical knowledge from nursing, health sciences, and social sciences together with clinical practice in both hospital and community settings, provide professional nursing care based on knowledge derived from theories and researches; synthesize theoretical and empirical knowledge from nursing, scientific and humanistic discipline with practice. Graduates work as beginning practitioners in a wide range of health care setting ${ }^{(28)}$.

Concerning acquisition of knowledge, it is releaved from the result that the students in both groups had nearly the same scores in airway suctioning knowledge test before teaching interventions and this may be explained by the same studying of adult airway suctioning in the previous year which is not greatly different than pediatric airway suctioning.

The finding of this study revealed that, that there were no statistically significant difference among the control group compared to study group regarding posttest mean scores of knowledge. The rational for why the control group achieved satisfactory score of knowledge in posttest in this study may be due to both groups were learned the same content regarding 
airway suction by the same instructor. Additionally the low adaptability of the students in the study group in using computer based learning module, as it is the first time for them to deal with. Extra time may be needed by the students in the computer lab to revise the whole module again.

This finding was in agreement with Abdalla et al(2013) who reported in his study that there were no statistically significant difference regarding immediate posttest mean score of knowledge between both groups teached by E-learning and traditional teaching methods regarding critical care nursing ${ }^{(29)}$ The finding was also similar to that of Udupa and Madhukar (2011) Who stated that no significant difference between traditional and computer assisted learning regarding immediate posttest mean scores acquiring knowledge ${ }^{(30)}$. The previous finding was contradicting with Kinney and Henderson (2008) who stated that significant differences between traditional lecture and e learning regarding immediate posttest mean scores of knowledge ${ }^{(31)}$.

Comparing between the two groups as regards knowledge pre/post module implementation by two teaching methods, the finding of current study showed that there were a highly statistically significant differences between pre and posttest mean scores of knowledge for the control and study groups. The finding indicated improvement of students' knowledge regarding airway suction. The improvement in the study group knowledge could be attributed to the effect of the module only, since the baseline knowledge in the two groups pre module implementation was the same. The module gave them the basic knowledge and the students in this young age have higher motivation and ability to acquire extra skills and knowledge.

The previous finding were in agreement with Abd Al-Rahman,(2009), who reported in here study that there were highly statistically significant differences between pre and posttest mean scores of knowledge for both lecture and computer assisted methods of learning cardiac disease ${ }^{(32)}$. Also the findings are in agreement with Abdalla et al(2013) who reported in his study that there were a highly statistically significant difference between pre and posttest mean scores of knowledge for both E-learning and traditional teaching methods regarding critical care nursing ${ }^{(29)}$. While, these findings are in contrast to the findings of Eaton-Spiva\&Day (2011) and Durmaz et al (2012) who found no significant differences for experimental group who used computer assisted learning course and control group who used 
traditional learning method in knowledge acquisition at immediate follow up ${ }^{(33,34)}$.Also the finding of Sebraetal (2004) found that there were no statistically significant difference between computer aided multimedia group and lecture group in post test score of knowledge ${ }^{(35)}$. The finding of the study recorded by Remie (2008) stated that the lecture group had a higher some score in MCQ compared to elearning group ${ }^{(36)}$.

Concerning retention of knowledge the present study found that the students who used computer based learning achieved higher scores regarding definition, purpose, methods, complication and principles for airway suction than in case of traditional learning methods at 2 weeks and 8 weeks follows up. These knowledge items were containing numbers and a lot of consecutive steps that made it more liable to be forgotten by time. This finding may be attributed to simulator like photos, audio, and videos in computer based learning module serves as cues to retrieve information.

Moreover, the findings in current study demonstrate that there were no statistically significant difference in the study group knowledge regarding all items of knowledge at immediate and 2weeks, immediate and 8 weeks, and 2 weekes and 8 weeks periods .According to these results, it can be said that the knowledge level of the study group students were at the same level from the beginning of the periods so the instruction is so lasting. This may be attributed to computer instruction allows person to interact in the learning situation; he or she can find information, respond to questions, manipulate variables and solve problems. This point of view is in agreement with Smaldino et al(2012) and Deyoung (2009) who stated that computer assisted instruction makes learning more intereting and memorable and help the learner maintains control of the learning process, its speed and order ${ }^{(27,37)}$.

These finding are in the same line with the results reported by Chiu et al (2009) and Bloomfield et al (2010) who found that nursing students achieved better knowledge retention when using computer assisted learning. These findings are in contrast to the finding of Kelly et al(2009) and Fernandz Aleman et al(2011) who reported that both teaching methods resulted in similar knowledge retention $(38,39,40.41$,$) .$

Concerning the relation between study and control group regarding airway suction knowledge items, the current study reported that, there were statistically significant difference between them at 2 and 8 weeks follow up, this may be attributed to the students in the study group 
take the advantages of computer based learning which include nonjudgmental approach, endlessly patience, setting the students own speed of learning, increased access to information, and instructional consistency. These findings are in agreement with finding of Kroncke (2010) who reported that students performing the computer based practical course(CPC) demonstrated a statistically significant knowledge retention compared to students who performed the laboratory experiment $^{(42)}$.

The results documented by Jenkens (2008) who found that there were no statistically significant difference between the score of the students in the intervention group (computer assisted learning) and control group (traditional lecture teaching).These findding was in the same line with Ricer (2005) who reported that there no statistically significant difference between both group who learned by computer and traditional learning methods in retention of materials ${ }^{(43,44) \text {. }}$

With regard to acquisition of skill performance, the finding of the present study documented that there was improvement in performance level of both groups at immediate follow up using both teaching methods but computer based learning method produce significant gain in performance level than traditional method. The students learned with CBL achieved higher scores regarding skill performance of assessment signs and symptoms indicating upper airway for natural and artificial airway suction than in case of traditional teaching methods, at immediate follow up. This may be attributed to recording the procedure that allow students to review the demonstration as needed until they master the skill and more interest provoked by new learning environment. These finding are in agreement with McTigue et al (2009) who found that nursing students achieved better assessment scores for skin tears when using an e learning programs ${ }^{(45)}$.

Also these findings are in agreement with Leflore et al (2011) and Guise et al (2012) who reported that students achieved higher skill performance scores using CAL compared to traditional learning methods ${ }^{(46,47)}$. While these findings are in contrast with the findings of Durmaz et al(2012) who found equivalent results in skill performance outcomes in both groups $^{(34)}$.

The finding of the present study illustrate that, students learned with CBL achieved higher scores regarding skill performance of implementation for natural and artificial airway suction than in case of traditional learning methods at immediate follow up. It was clear that those students with CBL 
were performing most of the procedure steps sequentially but in case of students with traditional teaching methods; the majority of them were forgetting to perform one step or more or were performing it in wrong sequence. This may be due to the students in CBL were able to repeat the demonstration at any point and for any number of times they want in contrast to the students in traditional group who are shyness to ask the instructor the repetition when losing their attention during demonstration.

The lower scores of the control group may be due to some limitations with demonstration method such as non-flexible pacing in which not all students may be able to follow the demonstrations pace of presentation, and students do not get direct hands on experience unless they are following along as the teacher demonstrates steps or skills, and limited view in which not all students have an equal view of the demonstration, thus possibly missing some aspect of the experience.

These findings are in agreement with the findings of Hou et al (2008) who reported that students achieved higher scores in skill performance in implementation and demonstration regarding cardiac auscultation when using computer aided auscultation learning system for using technique instruction at immediate follow up $^{(48)}$. Also the finding are in agreement with Bruce et al (2009) who reported that students achieved higher scores in skill performance of implementation regarding nursing management of cardiac arrest when using computer assisted human patient simulator, at immediate follow up $^{(49)}$. While these finding are in contrast to the findings of Bloomfield et al(2010) who found equivalent results at immediate follow up for CAI and conventional teaching methods groups ${ }^{(38)}$.

The finding of the present study illustrate that, students learned with CBL achieved higher scores regarding skill performance of post care and documentation for natural and artificial airway suction than in case of traditional learning methods at immediate follow up . This may be attributed to the computers individualize learning to an extra ordinary degree as learners can repeat information and computer program never get tired of repeating the same information. These finding are in the same line with Tseng et al(2012) who reported that students achieved higher skill performance scores using CAL compared to traditional learning methods ${ }^{(50)}$. While these findings are in contrast with the findings of Eaton Spiva and Day(2011) and Bloomfield et al (2010) who found equivalent results in skill performance outcomes in both 
groups ${ }^{(33,38)}$.Also the finding of Shenetal (2007) reported that traditional mode students have achieved slightly better performance in examination in comparison with on line mode students ${ }^{(51)}$.

Regarding retention of performance, the findings of the present study documented that students who use CBL achieved higher scores regarding skill performance of assessment, preparation, implementation, post care, and documentation for natural and artificial airway suction than in case of traditional teaching methods at 2and 8 weeks follow upand this may be attributed to the ability of the CBL module to stimulate the learning environment through audio, videos, and graphics that help the students to build up the procedure steps in a chain that would strengthen the network of the memory. These findings were in agreement with Abdalla et al (2013) who documented that the students studied with E learning method achieved higher mean scores than traditional teaching methods group regarding oxygen therapy, suction, pulse oximetery and central venous pressure measuring and caring ${ }^{(30)}$.

\section{Conclusion:}

Based on the results of the present study, it can be concluded that students studied with computer based learning method showed a significant improvement on knowledge and skill retention in relation to airway suctioning than students studied with traditional learning method.

\section{Recommendations:}

1. Medical and nursing education programs should adopt computer based learning in undergraduate education, and should support the introduction of computer based learning as an important step in curriculum development especially in training on high risk disciplines such as resuscitation, gavage feeding, and drug administration.

2. The use of computer based learning for the acquisition of specific clinical skills in specialties such as pediatrics, emergency medicine, intensive care, and obstetrics.

3. Computer based learning should be used in combination with traditional teaching method to further enhance the students' satisfaction and increase their skill acquisition level.

4. Establishing more training courses with university professors to develop their skills in electronic design and web applications that enable faculty member to use a variety of integrated strategies and employ these tools in the educational process.

5. This study should be replicated with more participants and at several universities with different cultures 
and/or ages to determine measurable outcomes of computer based learning and to generate larger statistical power with a diverse group of students.

6. Replicate the study with more variables including attitude toward using computers and teacher and students motivation

\section{References:}

1. Fortune M, Shifflett B and Sibley R. A comparison of on line (high tech) and traditional (high touch) learning in business communication courses in Silicon Valley. Journal of Education for business. 2006;81(4):210-214..

2. Benedetto O. Does technology influence teaching practices in the classroom? Paper presented at the national educational computing conference.2005.philadelphia.Bethesda ,Meryland:Instructional technology center. Available at: Dibenedetto@Stpsb.Org.

3. Kilbridge $\mathrm{P}$ and Classen D. The informatics opportunities at the intersection of patient safety and clinical informatics. Journal of the American Medical Informatics Association.2008; 15(4): 397-407.

4. Mahmood S. Examining the mathematics performance of developmental mathematics pupils when computer-assisted instruction combined with traditional instruction .Texas Southern University: United States-Texas.2006; 3 .

5. Renshaw $\mathrm{C}$ and Taylor $\mathrm{H}$. The Educational Effectiveness of Computer-Based Instruction. Computers and Geosciences Journal.2000; $26 \quad$ (6) :677682Dipchand A, Friedman J. The Hospital For Sick Children Handbook Pediatrics.11thed. Canda: Saunders ElsevierCo.,2009;664-86.

6. Leach A and HaunD.Deliver the lesson now, just in time training. Journal of medical laboratory observer.2003;35(7):2-46.

7. Waddill D. Action e learning, the of action learning on the effectiveness of a management level web based instruction. Journal of educational technology.2004;30(5):35-37.

8. Stem S. Computer assisted medical education, Current and potential roles. Prespectives in biology and medicine.2008;57(1):22.

9. Bastable S. Nurse as educator principles of teaching and learning for nursing practice. 3rd ed. London: Jones and Bartlett Co.,2008; 429-443.

10. Kandeel $\mathrm{N}$ and Ibrahim $\mathrm{Y}$. The Impact of Information Technology on Teaching and Learning: Student Nurses' Perspectives. International 
Journal Information \& Communication Technology.2009; 6 (3):32.

11. American Association of Critical Care Nurses,(2011): Critical NursingSkills\& Technique.Availablefrom:http://www.e how.com/way_5704953_criticalnursing-skills-technique.html.

12. Alhirish M. Critical care Nurses' application of evidence-based guidelines for preventing ventilator associated Pneumonia.Doctral thesis. Faculty of nursing, Alexandria University. 2010; 2.

13. Jones A and Batlrt R. Respiratory Care Principle And Practice.2th ed. USA: LLC co., 2012;410.

14. Morrow B AND Argent A. A comperhensive review of pediatric endotracheal suctioning: Effects, indications, and clinical practice.Pediatriccrtical care Journal. 2004;9(5):465-77.

15. Guglielminotti J, Alzieu M, Maury E, Guidet B and OffenstadtG.Bed side detection of retained trachea bronchial secretions in patients receving mechanical ventilation.2000;118(4) :1095-9.

16. Kelsey $\mathrm{J}$ and Carey M.Clinical skills in child health practice.Londen: Churchillivingstone co., 2008;214-220.
17. Dixon M. Practice in children nursing.2nd ed. Londen: Churchillivingstone co.,2008;273-76.

18. Newmarch C. Ca ring for the mechinichaly ventilated patient .Nursing standard Journal.2006 ;20(17):55-64.

19. Criag H. Asurvey of neonatal suction techniques performed by registerd nurses. Master thesis.Graduate college, Marshal university.2002;1-10.

20. Ba-Alwi A. Impact of closed vesus open tracheal suction system on the occuance of ventilator associated pneumonia. Doctoral thesis.Faculty of nursing, Alexandria University. 2008;27-54.

21. Day T, Farnell $\mathrm{S}$ and Willison B. Suctioning: areview of current research recommendations. Intensive circit care nurse. 2007;18(2):79-89.

22. El Arousy W. The effect of pulmonary hygiene on the occurance of pulmonary complications in neonates undergoing abdominal surgery. Doctoral thesis.Faculty of nursing. Aexanderia University.2005;4-14.

23. Day T, Tracheal suctioning:when, why and who.Nursingstandered Journal. 2013;28(30):36-38. 
24. Martin D, Mhyre M and Shanks SM. Emergency tracheal intubations at a university hospital:Airway outcomes and complications anthesiology Journal.2011;114(5):42-8.

25. Ameican Association of Respiratory Care:Clinical practice guidelines, endotracheal suctioning of mechanichally ventilated patient with artificial airways.Respiratory care Journal. 2010;55(6):254-62.

26. Deyoung S. Strategies for nursing education.2nded.United State of America:Prentic Hall Co., 2009;137-1.

27. Michael $J$ and Tait M. Areview of evaluative studies of computer based learning in nurse education.Nurse education today Journal.2005;25:586-597.

28. Ellis H.Managing and co ordinating nursing care.3rded.Philidliphia. Lippincolt, William and wilkin co.,2000;13-28.

29. Abdella K, Karam O, Ahmed N and Abd-ElhakimE.The effect of e-learning versus traditional teaching methods on students performance regarding critical care nursing. Journal of advanced computer science and technology research.2013;3(2):83-98.

30. Kinney $S$ and Henderson D. Comparison of Low Fidelity Simulation Learning Strategy With
Traditional Lecture, Clinical Simulation in Nursing.2008;(4):15-18.

31. Abd Al-Rahman A. Using of computer-Assisted learning versus traditional education, unpublished thesis.Faculty of nursing, Ain Shams University .2009;92-100.

32. Eaton-spiva L and Day A.Effectiveness of a computerized educational module on nurses knowledge and confidence level related to diapetes.Journal for nurses in staff development.2011;27(6):285-9.

33. Durmaz A, Dicle A, Cakan E and Cakir S. Effect of screen based computer simulation on knowledge and skill in nursing students learning of preoperative and postoperative care management: a randomized controlled study.CIN:Computers, Informatics, Nursing.2012;30(4):196-203

34. Sebra D, Srougi M, Baptista R, Nesrallah L, Ortiz V and SigalemD.Computer aided learning vesusstandered lecture for under graduate education in urology.Journal of urology.2004;171(3)1220-1222.

35. Reime M, Harries A and Aksnes J. The most successful method in teaching nursing students infection control Elearning or lecture. Nursing Education Today Journal.2008,;28(7):798-806 
36. Smaldino E, Loether L and Russell D.International technology and media for learning, person education. 2012;9(1):123-10.

37. Bloomfield J, Reberts $\mathbf{J}$ and While A. The effect of computer-assisted learning versus conventional teaching methods on the acquisition and retention of hand washing theory and practice in pre-qualification nursing students: A randomized controlled trail, International journal of Nursing Studies.2010;(47):287-294.

38. Chiu S, Chang K, Sun T, Chang K, Tan $\mathrm{T}$, Lin $\mathrm{T}$, Hung $\mathrm{Y}$ and Yeh $\mathrm{S}$. The effectiveness of interactive computer assisted instruction compared to videotaped instruction for teaching nurses to assess neurological function of stroke patient. Journal of nursing studies.2009; 46(12):1548-56.

39. Kelly M, Lyng C, McGrath M and Cannon G. Amulti method study to determine the the effectiveness of and student attitude to on line instructional videos for teaching clinical nursing skills.Nurse education Journal.2009;29(3):292-300.

40. Fernandez Aleman J, Carrillo $G$ and Rodriguez J. Effects of competitive computer assisted learning versus conventional teaching methods on the acquisition and retention of knowledge in medical surgical nursing student. Nurse education today Journal.2011;31(3):866-871.

41. Kroncke D. Computer based learning versus practical course in pre-clinical education: acceptance and knowledge retention.2010;32(5):408-418.

42. Jenkens S, Goel $\mathrm{R}$ and Morrell $\mathrm{P}$. Computer assisted instruction versus trsditional lecture for medical student teaching of dermatology morphology.Arandomized control trial. Journal of the American Academy of dermatology.2008;59(2):255-259.

43. Ricer R and FilakA.Doesahigh tech (computerized,animated powerpoint) presentation increase retention of material compared to a low tech (Black on clear overhead)presentation. Journal of teaching and learning in medicine.2005;17(2):107-111.

44. McTigue T, D, Andrea S, DoyleMunoz $\mathrm{J}$ and Forrester D. Efficiency of a skin tear education program, improving the knowledge of nurses practicing in acute care settings.Journal of wound, ostomy and continence nursing.2009;36(5):486-92.

45. Leflore J, Thomas P, Zielke M, BussFrank M, McFaddan B and Sansoucie D. Educating neonatal nurse practionaires in the 21th century.Journal of neonatal and 
perinatal nursing. 2011;25(2):200-5.

46. Guise V, Chambers $M$ and ValimakiM.What can virtual patient simulation offer mental health nursing education. Journal of psychiatric and mental health nursing.2012;19(5):410-8.

47. Hou C, Chen Y, Chuang C, Chiu Y and Tsai M. Computer aided auscultation learning system for nursing technique instruction,Annual international conference in medicine and biology society.2008; $1575-8$.

48. Bruce S, Scherer Y, Curran C, Urschel D, Erdley S and Ball L.A collaborative exercise between graduate and undergraduate nursing students using acomputer assisted simulator in a mock cardiac arrest.Nursing education perspectives. 2009;30(1):22-7.

49. Tseng K, Liou $T$ and Chiu $H$. Development of a computer aided clinical patient education system to provide appropriate individual nursing care for psychiatric patients. Journal of medical systems.2012;36(3):313-5.

50. Shen Q, Chung J, Chailis D and Cheung R.A comparative study of student performance in traditional mode and on line mode of learning. Journal of computer application in engineering education.2007;1(1)30-40. 